\title{
Patterns of polychaete diversity in selected tropical intertidal habitats
}

\author{
CHRISTOPHER R.S. BARRIO FROJÁN ${ }^{1}$, M.A. KENDALL ${ }^{2}$, G.L.J. PATERSON ${ }^{3}$, \\ L.E. HAWKINS ${ }^{4}$, S. NIMSANTIJAROEN ${ }^{5}$ and C. ARYUTHAKA ${ }^{5}$ \\ ${ }^{1}$ Centre for Environment, Fisheries and Aquaculture Science, Remembrance Avenue, Burnham-on-Crouch, \\ Essex CM0 8HA, UK. E-mail: chrib@nhm.ac.uk \\ 2 Plymouth Marine Laboratory, Prospect Place, Plymouth PL1 3DH, UK. \\ ${ }^{3}$ Department of Zoology, The Natural History Museum, Cromwell Road, London SW7 5BD, UK. \\ ${ }^{4}$ School of Ocean and Earth Science, Southampton Oceanography Centre, European Way, Southampton SO14 3ZH, UK. \\ ${ }^{5}$ Department of Marine Science, Faculty of Fisheries, Kasetsart University, Bang Khen, Bangkok 10900, Thailand.
}

\begin{abstract}
SUMMARY: Few studies have quantitatively compared benthic macrofaunal assemblages between different tropical intertidal habitats over differing spatial scales. The present study uses spatially nested material from vegetated (seagrass) and nonvegetated (mudflat) habitats in SW Thailand to address this issue. Polychaetes were the numerically dominant component of benthic assemblages throughout the region, comprising over $74 \%$ of the total macrofauna. Despite great within-site and sample variation, based on species diversity, polychaete assemblages were mostly site-specific. Not so visibly obvious were the evident differences in polychaete assemblages between habitats. The spatial pattern of polychaete diversity is explored.
\end{abstract}

Keywords: Polychaeta, Andaman Sea, tropical intertidal habitats, spatial scale.

RESUMEN: PATRONES DE DIVERSIDAD DE POLIQUETOS EN HÁBITATS INTERMAREALES TROPICALES SELECTOS. - Pocos estudios han comparado cuantitativamente el macrozoobentos entre diferentes hábitats intermareales tropicales a diferentes escalas espaciales. Para remediar esta situación, esta investigación utiliza y compara material colectado en praderas marinas y zonas sin vegetación en la costa suroeste de Tailandia a diferentes escalas espaciales. Los poliquetos formaron la mayor parte del zoobentos, constituyendo el $74 \%$ del total. Pese al alto nivel de variación entre muestras, basado en la diversidad de especies, los conjuntos de poliquetos mostraron mayor afinidad a su lugar de colecta. Diferencias entre cada hábitat, aunque difíciles de apreciar a simple vista, son corroboradas estadísticamente. Se exploran cambios en la diversidad asociados con cambios en la escala espacial.

Palabras clave: Polychaeta, mar de Andaman, hábitats tropicales intermareales, escala espacial.

\section{INTRODUCTION}

There are many studies on species richness of shallow marine soft sediments, especially as benthic communities are widely used for monitoring the 'health' of coastal systems. However, while data are probably representative of intertidal and coastal areas in temperate regions, quantitative data from sub-tropical and tropical areas are extremely sparse. Given the growing interest in small and broad scale biodiversity comparisons, there are still only a small number of tropical data sets that are sufficiently comprehensive and/or spatially explicit that they stand comparison with more recent information from higher latitudes (Alongi, 1990; Constable, 1999; Gray, 2002).

The benthic biota of the Andaman Sea coast of Thailand has recently been the subject of a number of scientific studies, mostly comprising taxonomic monographs of newly discovered species 
(Nateewathana and Hylleberg, 1991; Nateewathana, 1992; Eibe-Jacobsen, 2002) and descriptive macrofaunal abundance accounts (Petersen and Curtis, 1980; Boonlert, 1992; Dexter, 1996; Meksumpun and Meksumpun, 1999; Angsupanich and Kuwabara, 1995, 1999; Reise, 1991). Only McIntosh et al. (2002) calculate and compare macrofaunal diversity of the region, and none compare macrobenthic diversity between different habitats. In this study, we deal with this information vacuum by quantitatively characterizing and comparing the composition and structure of the macrofaunal component of the benthic communities found in intertidal vegetated (seagrass) and non-vegetated (mudflat) habitats of southwest Thailand, whilst at the same time providing the much-needed, purpose-collected data which will eventually enable small and broad-scale comparisons of benthic biodiversity.

\section{METHODS}

\section{Study area}

The sites investigated are situated on the Andaman Sea shore on the western coast of Thailand and are distributed over approximately 200 $\mathrm{km}$ of coastline (Fig. 1). This stretch of shoreline is characterized by mangrove forests, small estuaries, patchy seagrass beds and long sandy beaches. Poorly developed fringing reefs are also present around islands and rocky outcrops. Two seasons can be distinguished: the wet southwest monsoon season, which prevails between May and October, and the northeast monsoon, or dry season, between November and April. The wet season is characterized by heavy rainfall and strong westerly onshore winds which create continual moderate-to-high wave action, whereas during the dry season the western coastline experiences no significant rain, limited wind and a reduced intensity, frequency and height of waves. The semidiurnal tidal amplitude ranges from 1.1 to $3.2 \mathrm{~m}$ with a mean of about $2.2 \mathrm{~m}$ (Chansang and Poovachiranon, 1994).

\section{Data collection}

For this work, ten exposed sites at low tide (Table 1) at three locations (Northern, Central and Southern) were selected to represent two major intertidal sediment habitat types observed in the area, namely non- vegetated organic-rich mud and vegetated (seagrass) sediments. Macrofauna was sampled in the dry season - during November 2001 (Northern and Central locations) and January 2003 (southern location) - using a $30 \mathrm{~cm}$ diameter (area: $0.07 \mathrm{~m}^{-2}$ ) plastic tube corer inserted to a maximum depth of $40 \mathrm{~cm}$. Six cores were taken at each site within an undisturbed area measuring $20 \mathrm{~m}$ x $30 \mathrm{~m}$, with a minimum distance of $10 \mathrm{~m}$ between each core. Excavated sediment samples were bagged and fixed in $8 \%$ formalin for a minimum of 48 hours. Bags were regularly turned to homogenise the sediment and ensure thorough fixation of the macrofauna. Prior to analysis, sediment samples were suspended in water, poured into a $0.5 \mathrm{~mm}$ mesh sieve and gently agitated on a container filled with water. The sieve residue was stored in $70 \%$ alcohol until sorting under a dissection microscope. All organisms were removed, counted and classified into the following taxonomic groups: Polychaeta, Crustacea, Echinodermata, Mollusca, and 'Other'. Polychaete worms were further identified either as already described species, or allocated into morphospecies. Unclassifiable specimens (juveniles or unrecognisably damaged complete individuals) were counted but omitted from ecological analyses.

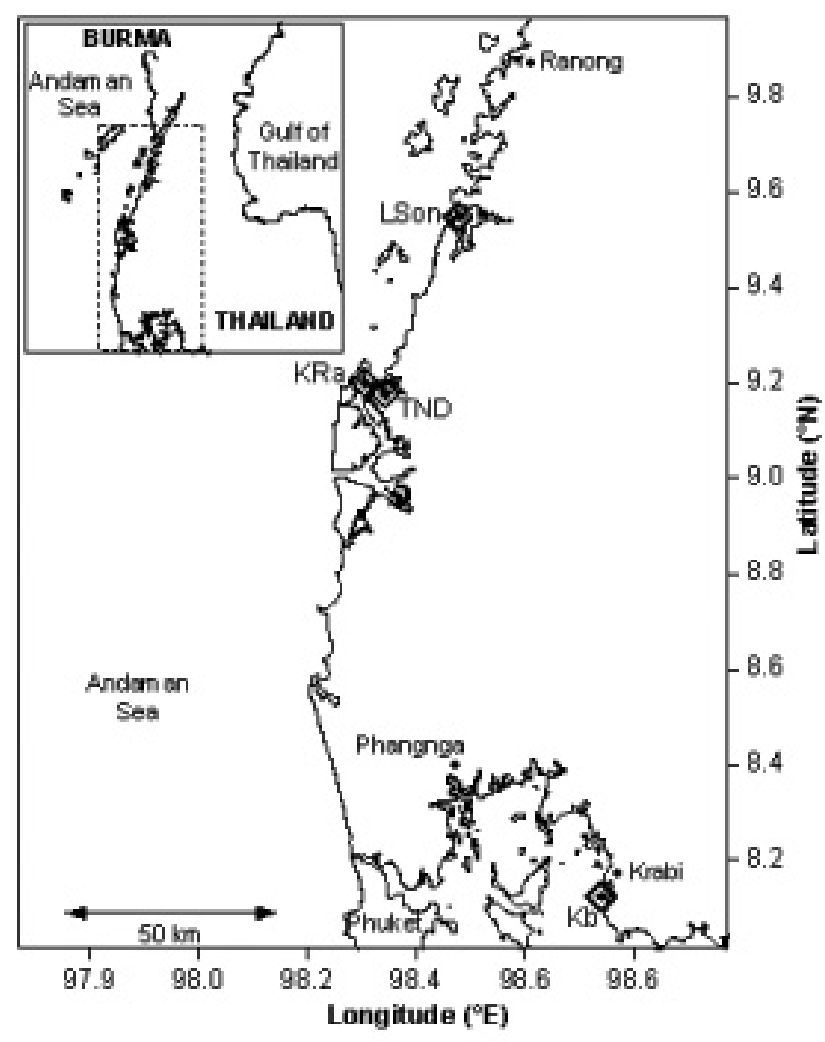

FIG. 1. - Map of study area. Site abbreviations: LSon = Laem Son; $\mathrm{TND}=$ Thung Nang Dam; KRa $=\mathrm{Ko} \mathrm{Ra} ; \mathrm{Kb}=$ Krabi. 
TABLE 1. - Summary of sampling site characteristics. Site abbreviations: LSon1 = Laem Son 1; LSon2 = Laem Son 2; TND(N)= Thung Nang $\operatorname{Dam}($ North); TND $(\mathrm{S})=$ Thung Nang Dam (South); KRa(N) = Ko Ra (North); KRa(S) = Ko Ra (South); Kb1a = Krabi 1a; Kb1b = Krabi 1b; $\mathrm{Kb} 2 \mathrm{a}=\mathrm{Krabi} 2 \mathrm{a} ; \mathrm{Kb} 2 \mathrm{~b}=$ Krabi $2 \mathrm{~b} . \%$ Sand refers to the combined proportion of sediment retained on $250 \mu \mathrm{m}$ and $125 \mu \mathrm{m}$ mesh-size sieves. Habitat abbreviations: N-V = Non-vegetated; $\mathrm{V}=$ Vegetated. Seagrass species abbreviations: $\mathrm{Cr}=$ Cymodocea rotundata, Ea $=$ Enhalus acoroides, $\mathrm{Hb}=$ Halophila beccarii, $\mathrm{Ho}=$ Halophila ovalis .

\begin{tabular}{llllll}
\hline Site & Latitude ${ }^{\circ} \mathrm{N}$ & Longitude ${ }^{\circ} \mathrm{E}$ & Habitat & Sand \% range & Date sampled \\
\hline LSon1 & 98.3397 & 9.24970 & $\mathrm{~N}-\mathrm{V}$ & $51-58$ & Nov-2001 \\
LSon2 & 98.3333 & 9.22531 & $\mathrm{~V}$ Hb & $37-47$ & Nov-2001 \\
TND(N) & 98.3099 & 9.23375 & V Ho, Cr & $64-78$ & Nov-2001 \\
TND(S) & 98.2939 & 9.20944 & V Ho, Cr & $54-72$ & Nov-2001 \\
KRa(N) & 98.4960 & 9.55679 & N-V & $52-75$ & Nov-2001 \\
KRa(S) & 98.4913 & 9.57767 & N-V & $59-71$ & Nov-2001 \\
Kb1a & 98.7525 & 8.12883 & V Ho, Ea & $56-70$ & 6 \\
Kb1b & 98.7528 & 8.12867 & N-V & $87-100$ & Jan-2003 \\
Kb2a & 98.7393 & 8.14750 & V Ho, Ea & $50-70$ & Jan-2003 \\
Kb2b & 98.7392 & 8.14800 & N-V & $46-62$ & Jan-2003 \\
\hline
\end{tabular}

The granulometry of the surface sediment at each site was analysed, quantifying the residue left on a series of graded mesh size sieves $(2.0 \mathrm{~mm}, 1.0 \mathrm{~mm}$, $0.5 \mathrm{~mm}, 0.25 \mathrm{~mm}$ and $0.125 \mathrm{~mm}$ ) and expressing each as a proportion of the total volume of sample (Holme, 1971).

\section{Ecological analysis}

Polychaete assemblages were compared between sampling sites and habitats using the ShannonWiener diversity index $\left(H^{\prime} \log _{2}\right)$, Simpson's dominance index $\left(C^{\prime}\right)$ and Pielou's evenness index $\left(J^{\prime}\right)$. A two-way crossed ANOSIM (analysis of similarities) test was performed on polychaete data from all samples with more than 30 individuals to ascertain the significance of differences in assemblages between habitats within locations and between locations. Analysis was based on Bray-Curtis similarity at all levels of data transformation. Results of analyses on square-root transformed data are presented, as these best illustrated the patterns observed. Patterns of similarity were visualised using non-metric multidimensional scaling (MDS). Species typifying assemblages were identified using SIMPER (similarity percentages). All of the above were performed using the PRIMER software package (Clarke and Warwick, 1997). Differences in faunal abundance values between habitats were tested using the ManWhitney (U) test.

Olmstead and Tukey's corner test for association (Sokal and Rohlf, 1995) was used to deduce the spatial distribution of polychaete species that make up the assemblages within the study area. This method allows graphing of the frequency of appearance of species in each of the sites sampled, expressed as a percentile, against the abundance of organisms. Species falling on either side of the mean values calculated for each axis separate into four categories: frequent and abundant (dominant) species; abundant and non-frequent (restricted or localised) species; non-frequent and non-abundant (rare or occasional) species; and frequent and non-abundant (common) species (Rodríguez Villanueva et al., 2003).

Following the terminology of Colwell and Coddington (1994), and using the EstimateS software (Colwell, 1997), species restricted to a single site (uniques), those present at exactly two sites only (duplicates), those represented by a single individual (singletons), and those represented by only two individuals (doubletons) were determined. The nonparametric Chao 2 method (Colwell and Coddington, 1994) was used to estimate the theoretical number of species expected within the whole sampling area.

\section{RESULTS}

\section{Faunal abundance and diversity}

The 60 cores analysed from all ten sampling sites yielded a total of 6,035 macrofaunal individuals in a combined area of $4.2 \mathrm{~m}^{2}$. Polychaetes numerically dominated the community structure, contributing $74 \%$ (4,457 ind.) of the benthic macrofaunal individuals, followed by crustaceans (11\%; 691 ind., mostly amphipods and decapods), molluscs (10\%; 575 ind., mostly bivalves), and others (5\%,285 ind., including sipunculans, brachiopods, turbellarians, enteropneusts, insects, cephalochordates and small fish). Echinoderms ( $<1 \%, 28$ ind.) mostly belonged to the class Ophiuroidea. 
TABLE 2. - Summary of polychaete benthic community parameters for all ten sampling sites. Site abbreviations as in Table $1 ; H^{\prime} \log _{2}$, Shannon-Wiener; J', evenness; C', Simpson dominance.

\begin{tabular}{|c|c|c|c|c|c|c|c|c|c|c|c|c|c|}
\hline \multirow[b]{2}{*}{ Site } & \multirow[b]{2}{*}{$\mathrm{n}$} & \multirow{2}{*}{$\begin{array}{l}\text { Density } \\
\mathrm{m}^{-2} \pm \mathrm{SE}\end{array}$} & \multicolumn{4}{|c|}{ Species richness } & \multirow{2}{*}{$\begin{array}{c}\text { Uniques } \\
\%\end{array}$} & \multirow{2}{*}{$\underset{\%}{\text { Duplicates }}$} & \multirow{2}{*}{$\underset{\%}{\text { Singletons }}$} & \multirow{2}{*}{$\begin{array}{c}\text { Dubletons } \\
\%\end{array}$} & \multirow[b]{2}{*}{$H^{\prime} \log _{2}$} & \multirow[b]{2}{*}{$J^{\prime}$} & \multirow[b]{2}{*}{$C^{\prime}$} \\
\hline & & & Mean \pm SE & Range & Total & $\mathrm{m}^{-2}$ & & & & & & & \\
\hline LSon1 & 517 & $1,231 \pm 286$ & $21 \pm 2$ & $13-30$ & 59 & 138 & 50.0 & 20.7 & 32.8 & 17.2 & 3.2 & 0.54 & 0.35 \\
\hline LSon2 & 635 & $1,512 \pm 203$ & $25 \pm 3$ & $11-35$ & 69 & 162 & 50.0 & 19.1 & 32.4 & 10.3 & 4.8 & 0.79 & 0.07 \\
\hline TND(N) & 456 & $1,086 \pm 109$ & $25 \pm 2$ & $20-33$ & 58 & 136 & 31.6 & 33.3 & 26.3 & 21.1 & 4.8 & 0.82 & 0.05 \\
\hline TND(S) & 425 & $1,012 \pm 91$ & $27 \pm 2$ & $20-32$ & 67 & 157 & 39.4 & 24.2 & 33.3 & 15.2 & 5.1 & 0.84 & 0.04 \\
\hline $\mathrm{KRa}(\mathrm{N})$ & 424 & $1,010 \pm 125$ & $24 \pm 3$ & $16-35$ & 67 & 157 & 48.5 & 22.7 & 33.3 & 19.7 & 5.0 & 0.83 & 0.05 \\
\hline $\mathrm{KRa}(\mathrm{S})$ & 557 & $1,326 \pm 173$ & $24 \pm 3$ & $13-32$ & 66 & 155 & 50.8 & 18.5 & 30.8 & 15.4 & 4.5 & 0.74 & 0.09 \\
\hline Kbla & 279 & $664 \pm 113$ & $19 \pm 1$ & $13-22$ & 55 & 129 & 50.0 & 22.2 & 40.7 & 16.7 & 4.8 & 0.84 & 0.05 \\
\hline Kb1b & 160 & $381 \pm 80$ & $11 \pm 2$ & $6-21$ & 31 & 74 & 41.9 & 19.4 & 25.8 & 22.6 & 4.0 & 0.81 & 0.11 \\
\hline $\mathrm{Kb} 2 \mathrm{a}$ & 348 & $829 \pm 118$ & $22 \pm 2$ & $14-32$ & 53 & 124 & 40.4 & 17.3 & 34.6 & 17.3 & 4.7 & 0.83 & 0.06 \\
\hline $\mathrm{Kb} 2 \mathrm{~b}$ & 656 & $1,562 \pm 316$ & $32 \pm 2$ & $27-40$ & 69 & 162 & 36.8 & 14.7 & 23.5 & 17.2 & 5.2 & 0.85 & 0.04 \\
\hline Total & 4,457 & $1,061 \pm 146$ & $23 \pm 1$ & $6-40$ & 179 & 43 & 33.1 & 16.9 & 14.0 & 16.9 & 6.0 & 0.81 & 0.03 \\
\hline
\end{tabular}

Mean macrofaunal density (ind. $\mathrm{m}^{-2} \pm \mathrm{SE}$ ) ranged from $819 \pm 109$ at Krabi 1a (Kb1a) to 1,648 \pm 171 at Thung Nang Dam (South) (TND(S)). Mean polychaete density ranged from $381 \pm 80$ at Krabi $1 b$ to $1,562 \pm 316$ at Krabi $2 b(\mathrm{~Kb} 2 b)$. The mean number of polychaete species per sample $( \pm$ SE) ranged between $11 \pm 2$ at Krabi $1 b$ to $32 \pm 2$ at both Krabi 2a and Krabi $2 b$, and the total number of polychaete species per site ranged between 31 and 69 (Table 2). Both the total number of polychaetes (n) and the number of polychaete species per site (S) were negatively correlated to mean\% sand (ranges given in Table 1) at each sampling site (regression values: $r_{\mathrm{n}}=0.739$, $P=0.007$, and $\left.r_{\mathrm{S}}=0.823, P=0.002 ; n=10\right)$. Differences in the abundance of both total macrofauna and polychaetes alone between combined vegetated and combined non-vegetated sites were not significant $\left(z<P_{0.05}\right)$. The difference in abundance of nonpolychaetous macrofauna between these two habitats was significant $\left(z>>P_{0.01}\right)$. Vegetated habitats harboured a greater number of polychaete species per sample than did non-vegetated habitats $(P=0.05)$.

Polychaetes were classified into 179 putative species-of which 62 (35\%) were already described-94 described genera and 35 families. 355 individuals collected $(8 \%)$ could not be classified beyond family level, as they were either juvenile, damaged or did not correspond with published taxonomic descriptions. The Chao 2 estimate of total area species richness gave $201 \pm 10$ (mean \pm SD). Unlike the total area species accumulation curve, the Chao2 estimate stabilised towards an asymptotic value (Fig. 2a). Species accumulation curves for each site showed little sign of stabilising towards asymptotic values (Fig. 2b). Species density values for each site ranged between 74 and 162 species $\mathrm{m}^{-2}$; the overall species density value was 43 species $\mathrm{m}^{-2}$.
Four samples (all in non-vegetated sites and divided equally between Laem Son 1 (LSon1) and Krabi 1b (Kb1b)) had Shannon-Weiner diversity index $\left(H^{\prime}\right)$ values below 2.5. The abundance of Nereis trifasciata (Grube, 1878) (58\% of individu-
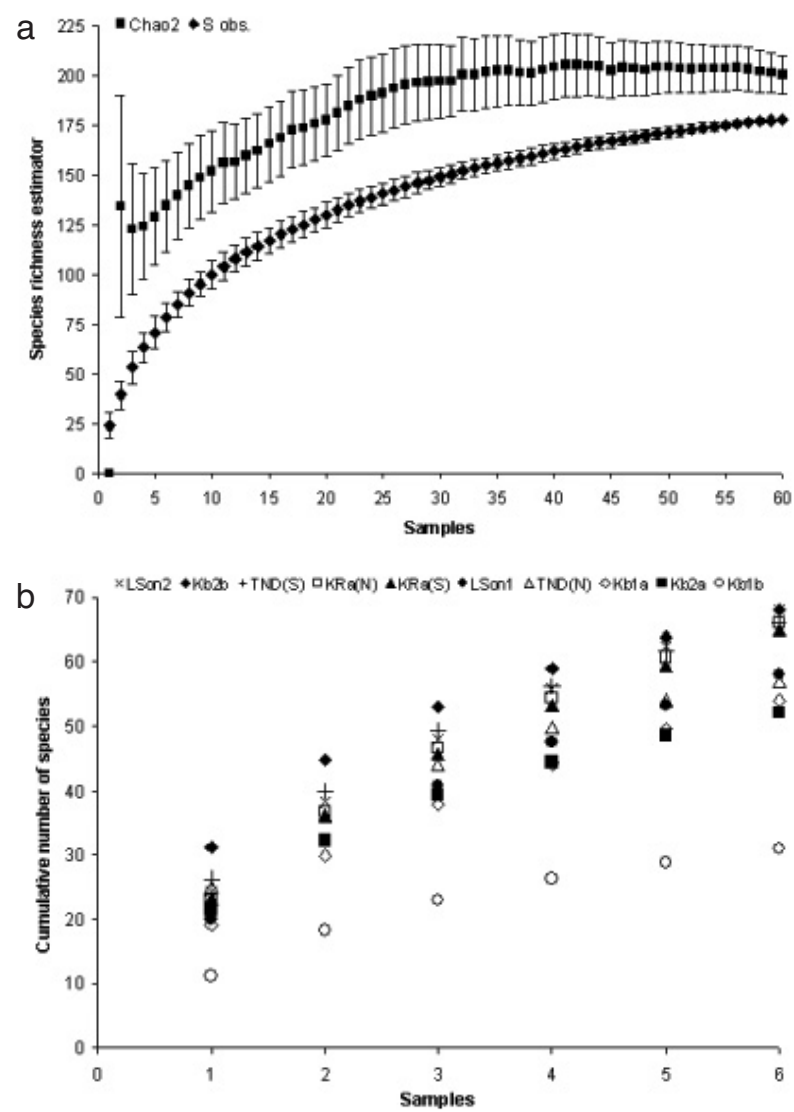

FIG. 2. - Species accumulation curves for the total area (a) and for each site individually (b). Estimators of species richness are the observed number of all species (S obs.) and the Chao2 estimator of true richness. Plotted values are means based on 50 randomisations of sample accumulation order (without replacement). Bars indicate \pm SD. Site abbreviations: LSon $1=$ Laem Son 1; LSon2 $=$ Laem Son 2; TND(N) $=$ Thung Nang Dam (North); $\operatorname{TND}(\mathrm{S})=$ Thung Nang Dam (South); $\mathrm{KRa}(\mathrm{N})=\mathrm{Ko}$ Ra (North); KRa(S) = Ko Ra (South); Kbla = Krabi 1a; $\mathrm{Kb} 1 \mathrm{~b}=$ Krabi 1b; Kb2a = Krabi 2a; Kb2b = Krabi 2 


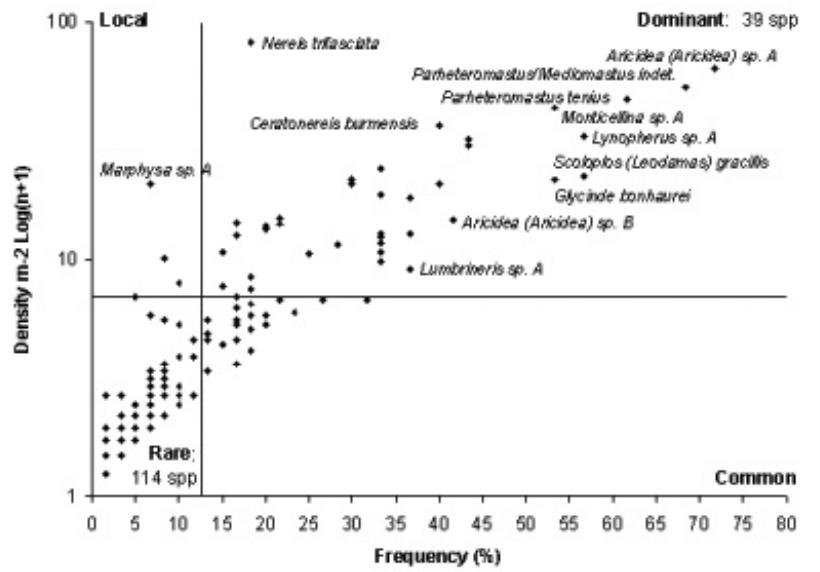

FIG. 3. - Relationship between frequency of appearance (\%) and abundance (ind $\mathrm{m}^{-2}$ ) of polychaete species for all cores. Some of the most abundant polychaete species are labelled.

als) was the likely cause at Laem Son 1. The same samples also had the two highest Simpson's dominance $\left(C^{\prime}\right)$ values $(\geq 0.7)$. Krabi 1 b not only harboured few individuals, but a large proportion of these $(27 \%)$ were Prionospio cornuta (Hylleberg and Nateewathana, 1991). Its $C^{\prime}$ values were above the overall average value for the study area. Site-specific $H^{\prime}$ values ranged from 3.2 at Laem Son 1 (LSon1) to 5.2 at Krabi $2 \mathrm{~b}$ (Kb2b) (Table 2). This was mirrored by site-specific C' values, which ranged from 0.04 at Krabi 2 b to 0.35 at Laem Son 2, and Pielou's evenness index ( $\left.J^{\prime}\right)$, which ranged from 0.54 at Laem Son 2 to 0.85 at Krabi 2 b (Table 2). There was no relationship between site species richness and any of the calculated diversity indices. Neither was any habitat-defining pattern in diversity indices apparent. Inter-habitat differences in diversity were small, nonvegetated sites combined having a lower $H^{\prime}$ value (5.6) than combined vegetated sites (6.0).

\section{Distribution of species}

The four most abundant polychaete families (51\% of all individuals) were Nereididae (607 ind.), Spionidae (602 ind.), Capitellidae (555 ind.) and Paraonidae (464 ind.). Families with the highest species richness were Spionidae (28 spp.), Capitellidae (17 spp.) and Nereididae (11 spp.). Of the polychaete species, only one occurred at all ten sampling sites; 59 species $(33 \%)$ occurred at one site alone (uniques) and 30 species (17\%) occurred at only two sites (duplicates). Across all sites, 25 species $(14 \%)$ were represented by a single individual (singletons) and 30 species (17\%) were represented by just two individuals (doubletons) (Table 2). Olmstead and Tukey's analysis, based on abundance and frequency of occurrence, indicated a total of 39 species as dominants (i.e. occurring at above

TABLE 3. - Polychaete species contributing to the dissimilarity between habitats and locations resulting form SIMPER analysis on squareroot transformed data ranked in decreasing order of their importance to the dissimilarity between the groups. Only species cumulatively contributing c. $25 \%$ to the dissimilarity are listed; C, Contribution.

\begin{tabular}{|c|c|c|c|c|c|c|}
\hline Species & $\begin{array}{c}\text { Average } \\
\text { abundance }\end{array}$ & $\begin{array}{c}\text { Average } \\
\text { abundance }\end{array}$ & $\% \mathrm{C}$ & Species & $\begin{array}{c}\text { Average } \\
\text { abundance }\end{array}$ & $\begin{array}{c}\text { Average } \\
\text { abundance }\end{array}$ \\
\hline
\end{tabular}

Treatments Vegetated and Non-vegetated (average dissimilarity: 77.6)

Nereis trifasciata

Aricidea (Aricidea) sp. A

Monticellina sp. A

Parheteromastus tenuis

Parheteromastus/Mediomastus indet.

Prionospio (Prionospio) sp. A

Goniada littorea

Ceratonereis burmensis

Scoloplos (Leodamas) gracillis

Lynopherus sp. A

Aglaophamus sp. A

Groups Northern and Southern

(average dissimilarity: 84.2)

$\begin{array}{lccc}\text { Nereis trifasciata } & 33.70 & 0.00 & 8.35 \\ \text { Ceratonereis burmensis } & 12.20 & 0.80 & 3.71 \\ \text { Parheteromastus tenuis } & 1.30 & 5.75 & 3.32 \\ \text { Parheteromastus/Mediomastus } \text { indet. } & 4.00 & 2.30 & 2.32 \\ \text { Lynopherus sp. A } & 3.90 & 2.70 & 2.03 \\ \text { Polydora tridenticulata } & 3.80 & 0.00 & 1.96 \\ \text { Glycinde bonhaurei } & 3.00 & 0.90 & 1.91 \\ \text { Lumbrineris cf. latrelli } & 0.00 & 2.85 & 1.83\end{array}$

Groups Central and Southern

(average dissimilarity: 80.3)

$\begin{array}{llll}\text { Aricidea (Aricidea) sp. A } & 8.88 & 1.40 & 3.60 \\ \text { Goniada littorea } & 5.17 & 0.00 & 3.43 \\ \text { Monticellina sp. A } & 6.54 & 1.15 & 2.92 \\ \text { Parheteromastus tenuis } & 2.04 & 5.75 & 2.91 \\ \text { Parheteromastus/Mediomastus } \text { indet. } & 5.29 & 2.30 & 2.80 \\ \text { Aglaophamus sp. A } & 3.83 & 0.00 & 2.52 \\ \text { Goniada sp. B } & 3.33 & 0.05 & 2.41 \\ \text { Prionospio (Prionospio) sp. A } & 3.46 & 1.80 & 2.25 \\ \text { Lynopherus sp. A } & 1.50 & 2.70 & 2.01 \\ \text { Lumbrineris } \text { cf. latrelli } & 0.00 & 2.85 & 1.93\end{array}$

Groups Central and Northern

(average dissimilarity: 80.8)

$\begin{array}{lccc}\text { Nereis trifasciata } & 0.00 & 33.70 & 8.15 \\ \text { Ceratonereis burmensis } & 0.29 & 12.20 & 3.68 \\ \text { Aricidea (Aricidea) sp. A } & 8.88 & 1.50 & 3.31 \\ \text { Goniada littorea } & 5.17 & 0.40 & 2.77 \\ \text { Monticellina sp. A } & 6.54 & 1.10 & 2.30 \\ \text { Goniada sp. B } & 3.33 & 0.10 & 2.22 \\ \text { Aglaophamus sp. A } & 3.83 & 0.50 & 2.15 \\ \text { Prionospio (Prionospio) sp. A } & 3.46 & 0.10 & 2.10\end{array}$



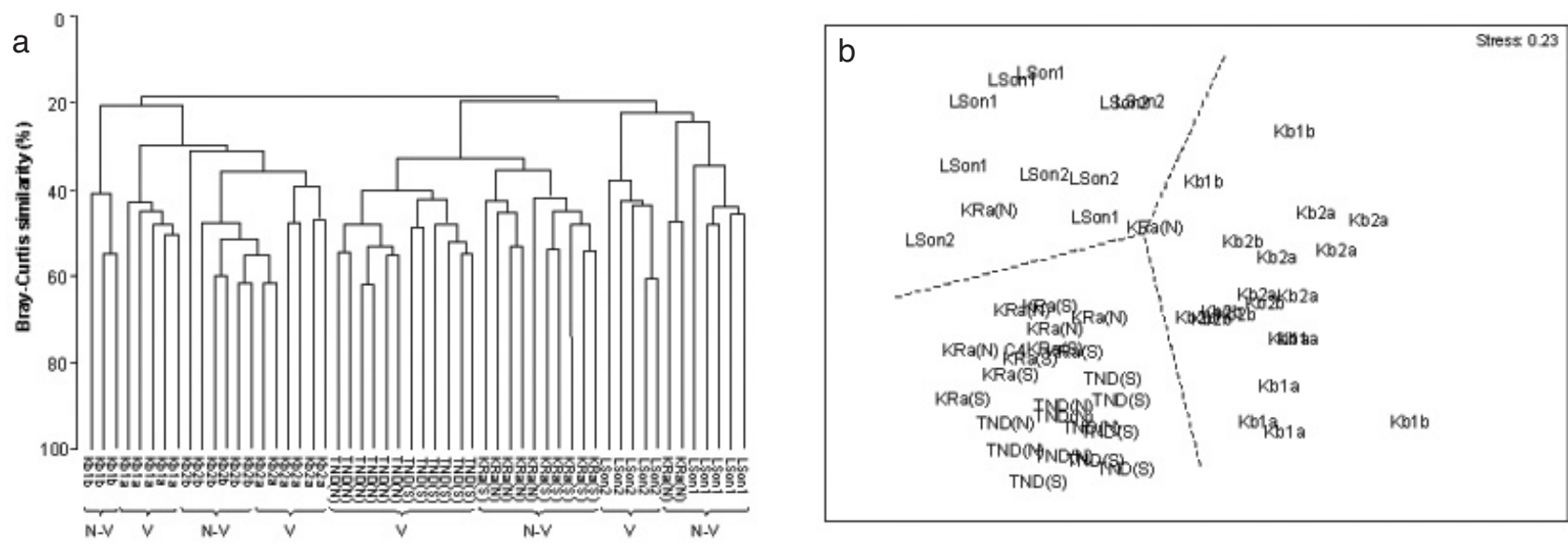

FIG. 4. - (a) Hierarchical clustering and (b) multidimensional scaling ordination of square root-transformed polychaete abundance data based on Bray-Curtis similarities from 54 core samples, each labelled according to site. Dashed lines roughly separate each of the three sampling locations. $\mathrm{N}-\mathrm{V}=$ non-vegetated, $\mathrm{V}=$ vegetated. Site abbreviations as in Figure 2.

average density and average frequency values), equivalent to $22 \%$ of the polychaete community. The dominant species overall were Aricidea (Aricidea) sp. A, Parheteromastus/Mediomastus indet. and Monticellina sp. A, present in $72 \%, 68 \%$ and $62 \%$ of samples, respectively (Fig. 3). 118 species $(66 \%)$ of the polychaete community were classified as local (i.e. occurring at below the average frequency). Of these, 114 species were also considered rare (i.e. also occurring at below the average density). The remaining 21 species (12\%) were considered as common or frequent in this study.

\section{Faunal assemblages in space}

Sample clustering is shown in Figure 4a. At 19\% similarity, samples in southern sites separated from all others, and at $20 \%$ similarity most samples from Northern and Central sites were separated. Within each location, samples clustered mostly with those from the same sampling site, only occasionally blurring differences between sampling sites (e.g. two Ko $\mathrm{Ra}$ (North) samples clustering together with similarly non-vegetated Laem Son 1) and between habitats (e.g. two samples in vegetated Krabi 2a clustering together with non-vegetated Krabi $2 b$ samples). Samples within each site did not show a high level of similarity to one another, as indicated by the long terminal branches. TND(N) samples showed highest similarity to each other, whereas samples in Laem Son 1 were the most dissimilar. Tests for differences in polychaete assemblages between locations were significant (ANOSIM Global $\mathrm{R}=0.859,0.1 \%$ significance level; pairwise tests among locations gave similar values), as were tests for differences between habitat groups averaged across all locations (ANOSIM Global $\mathrm{R}=0.517,0.1 \%$ significance level). Significance levels did not alter with increas-

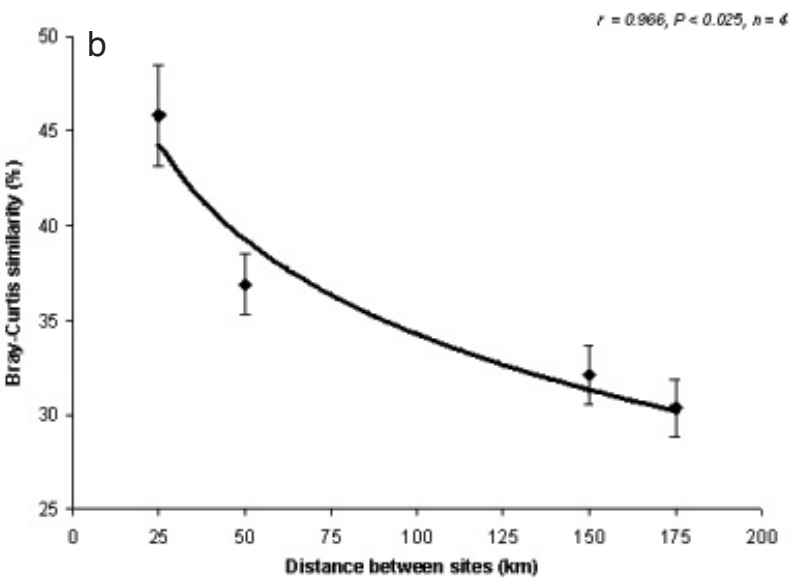

FIG. 5. - Bray-Curtis similarity (\%) between (a) all combinations of samples within each site and (b) all combinations of sites averaged over increasing distance intervals of $25 \mathrm{~km}$ plotted as a function of distance. Bars indicate \pm SE. 
ing or decreasing the severity of data transformation. The average Bray-Curtis dissimilarity between locations ranged from 80.3 to 84.2 , and average dissimilarity between vegetated and non-vegetated habitats was 77.6. Species responsible for $25 \%$ of the dissimilarity between assemblages at each pair of locations and habitats (as given by SIMPER analyses) are presented in Table 3. MDS ordination illustrated the difference in faunal composition at each of the three locations (Northern, Central and Southern) (Fig. 4b), but did not separate samples according to habitat. The high stress value of this plot (0.23) makes interpretation difficult.

Bray-Curtis similarities between all combinations of samples at each site were plotted against distance (Fig. 5a), and Bray-Curtis similarities between all combinations of sites were averaged over increasing distance (25 km units) (Fig. 5b). In both cases, similarity showed a significant inverse relationship with increasing distance. Again, different data transformations had no effect on the significance of these results.

\section{DISCUSSION}

\section{The nature of the community}

Intertidal vegetated habitats are thought to provide greater densities of food and more niches than non-vegetated habitats (Ansari et al., 1991; Edgar et al., 1994; Somaschini et al., 1994; Sheridan, 1997; Turner and Kendall, 1999). Comparative tests in this study did reveal a greater abundance of mostly epifaunal, non-polychaetous macrofauna in vegetated habitats but no significant difference in the abundance of the mostly infaunal polychaetes between habitats, a finding also reported by Edgar et al., (1994). Vegetated habitats harboured a greater number of polychaete species than non-vegetated habitats. Since no discrimination was made between infaunal and epifaunal polychaetes at the time of sampling, it remains unknown whether the proportion of polychaetes belonging to either group varied between habitats. It is safe to assume however, that increased habitat heterogeneity provided by seagrass was influential in its effect on polychaete community structure. Sediment granulometry was another influential factor, and the observed negative relationship between polychaete abundance, species richness and \% sand is typical of benthic assem- blages. Which environmental factor was mostly responsible for the observed patterns in faunal distribution remains to be seen and deserves further research.

Most of the numerically dominant and widespread polychaete species belonged to the surface and sub-surface deposit feeding families Capitellidae, Cirratulidae, Orbiniidae and Spionidae (as classified using Fauchald and Jumars, 1979), suggesting a food web heavily reliant on detritus from autochthonous (e.g. benthic macro-algae, seagrass) and allochthonous (e.g. mangrove leaf decomposition) sources. Carnivorous species belonging to the Amphinomidae, Nereididae and Goniadidae, as well as the partly herbivorous Paraonidae were also well represented in terms of abundance and frequency of occurrence, all of which is suggestive of a well-established community with an evolved food chain and reflecting a relatively stable environment. A distribution of individuals among the trophic groups such as the one observed appears to be characteristic of tropical tidal flats (Dittman and Vargas, 2001).

As in most ecological data sets, the majority of polychaete species were represented by a small number of individuals and the majority of individuals belonged to a few abundant species. In this case, the most abundant species (e.g, Nereis trifasciata, Scoloplos (Leodamas) gracilis, Parheteromastus tenuis) have previously been found in large numbers throughout the Indo-pacific region (e.g. Fauvel, 1932a, 1932b, 1953; Imajima, 1972; Baoling et al., 1985; Al-Hakim and Glasby, 2004). Half of the species encountered were severely restricted in range, occurring only in one or two sites, and one third of species were represented by either only one or two individuals. Based on Olmstead and Tukey's graphic analysis (Figure 3), almost two thirds of the species found were considered as rare. According to Pearson and Rosenberg (1978), unstressed sites show many rare and few common species along a stressor gradient. Conversely, stressed sites have fewer rare species and are heavily dominated by a few abundant species. Such a preponderance of rare species found by this study does suggest a relatively unstressed environment.

The abundance of macrofauna $(819 \pm 109-1,648$ \pm 171 ind $\mathrm{m}^{-2}$ ) in the present study was akin to that recorded in other tropical sedimentary habitat surveys (e.g. Angusupanich and Kuwabara, 1995, Patterson Edward and Ayyakkannu, 1992 ; Warwick 
and Ruswahyuni, 1987 ; Dittmann, 2000 ; Lara and Zamora, 1994 and review by Alongi, 1990). The range in proportion of polychaetes within the macrofauna (45-90\%)was also consistent with other studies conducted in the region (Patterson Edward and Ayyakkannu, 1992, Angsupanich and Kuwabara, 1995) and in equivalent habitats further afield (Turner and Kendall, 1999, and references in Alongi, 1990 and Hutchings, 1998).

\section{Species richness, diversity and taxonomic impediment}

The total number of polychaete species found in this intertidal study was 179 (from 4,457 individuals) belonging to 35 families. Phasuk (1992) published a list of 154 polychaete species (from 3,284 individuals) belonging to 39 families collected during the Fifth Thai-Danish Expedition in the Andaman Sea, and Aungtonya et al., (2002) list 145 species (from 1,101 polychaete lots) belonging to 37 families held in the reference collection at Phuket Marine Biological Centre (Thailand). The number of species obtained in this study relative to the total number of individuals collected is comparable with previous studies in the region. However, since many species are as yet undescribed, the difficulty in consolidating all existing knowledge of species identities, richness and diversity in the region remains overwhelming. Nonetheless, since there are no comparable intertidal polychaete surveys in the Andaman Sea, the present account provides a significant addition to our understanding of the region's ecology.

The Chao 2 estimate of total species richness reached an asymptote around 200 species after adding approximately half of the 60 samples taken (Figure 2a). The species accumulation curve showed little sign of reaching an asymptote after all samples were added. This does not suggest saturation, signifying that local species richness is determined primarily by regional richness (Gray, 2002). Applications of the Chao2 method in marine studies are few, but most suggest that Chao 2 underestimates the actual species richness (Ellingsen and Gray, 2002 ). Studies in other tropical intertidal and shallow water habitats have yielded between 96 and 233 polychaete species (see Table 1 in Hutchings, 1998), and generally fewer at higher latitudes (e.g. 60 by Edwards et al., 1992 ). An estimate of 200 may be an accurate estimation of the total number of species living in the intertidal habitats here studied; howev- er, inclusion of species encountered in other intertidal habitats in the region is likely to overshoot the present Chao 2 estimate.

Although a few individual samples were found to have low Shannon-Wiener diversity $\left(H^{\prime}\right)$ values, likely caused by localised aggregations of one particular species, site-wide diversity values were high, indicative of low faunistic dominance. This was indeed reflected by the relatively small values obtained from the Simpsons dominance index $\left(C^{\prime}\right)$, as well as high evenness $\left(J^{\prime}\right)$ values. Laem Son $1-$ the only site to stand out for its low diversity, evenness and high dominance values - was noted to have large numbers of Nereis trifasciata in many of its cores, yet it also harboured the average number of species encountered over the entire sampling area. In terms of qualifying habitat health, $H^{\prime}$ values greater than 4 , as were most found by this study, can be considered as an indication of a good and clean environment. However, $H^{\prime}$ has often proved to be relatively insensitive to the impact of various disturbances on the environment (Washington, 1984 ; Lydy et al., 2000 ), and therefore, any comparisons between sites, with other areas, or with future monitoring studies in the area currently investigated should be treated with caution.

\section{Polychaete assemblages}

The use of multivariate statistics gives a much more precise way of detecting changes in benthic assemblages in space and time than use of diversity indices (Gray et al., 1990 ). In this study, similarity analysis indicated a high level of dissimilarity among samples (within and between sites), as seen by the long terminal branch lengths in the dendrogram in Figure 4a. Low similarities within a dendrogram also denote high beta diversity (species turnover), suggesting that the environment under investigation is patchy at small spatial scales. However, despite this small-scale patchiness, differences between both habitats and among sampling locations were broad enough to be supported statistically (i.e. each location had a unique macrofaunal assemblage, yet assemblages in each habitat studied bore some resemblance to one another regardless of location). Significance testing with a two-way crossed ANOSIM test revealed that differences in polychaete assemblages from each of the habitats studied were significant at the $1 \%$ level, as were differences in assemblages at each of the three loca- 
tions. Results from the SIMPER analysis indicated that Nereis trifasciata, Aricidea (Aricidea) sp. A and Monticellina sp. A - all of which were more abundant in the vegetated samples - were important in differentiating between vegetated and non-vegetated habitats (Table 3). A higher abundance of N.trifasciata and Ceratonereis burmensis differentiated the Northern location from Central and Southern locations, whereas a greater abundance of Aricidea (A.) sp. A, Goniada littorea and Monticellina sp. A at the Central location differentiated it from the Southern location. Transformation of the data into presence/absence values served to dampen the influence of N. trifasciata and Aricidea (A.) sp. A, but did not diminish the influence of other top ranking species responsible for the differences observed. It is worth noting that abundant species were considered common throughout the study area

The abundance of benthic macrofauna is known to vary seasonally (see review by Alongi, 1990), thus differentiating faunal patterns observed in the present study may not necessarily persist at other times of the year. Moreover, it must not be overlooked that Southern locations were sampled 14 months after Central and Northern locations, therefore, differences between Southern and the other two locations may to some extent be attributed to temporal variation in faunal assemblage composition.

The large numbers of species encountered at only one or two sites (uniques and duplicates), the low number of shared species amongst sites, and the reduction of faunal similarity with increasing distance between samples and sites (Figures $5 \mathrm{a}$ and $5 \mathrm{~b}$, respectively) regardless of relative species abundance, are further clear indications of how the sedimentary habitats under study are physically heterogeneous on a relatively small scale. Selective preference by polychaetes of different within-habitat physical conditions is likely to be responsible for the observed faunal distribution patterns, however, given that over the total area encompassed by this study faunal similarity was only reduced by approximately one third, and that most of the discriminating species between habitats and locations were fairly common throughout, it is clear that at larger scales, the sediments and habitats investigated are more homogeneous than previously assumed. Habitats and locations may have harboured slightly different faunal assemblages, but how much of this variation is attributable to biogeographic processes is debatable. Inclusion of these data into province/oceanographic scale faunal analyses would greatly improve our understanding of intertidal polychaete diversity in the Andaman Sea.

\section{CONCLUSIONS}

The need for adequate description of tropical marine macrofaunal communities is a theme which has been raised repeatedly and strongly by a number of researchers. However, descriptive studies are of value only if they advance beyond the collection and recording of data to at least some level of ecological interpretation. This study has tested existing hypotheses and provided useful insights into the structure and function of a previously understudied area.

Where habitats are patchy and the vast majority of species are rare, it is seldom possible to collect and process enough samples to estimate species richness accurately. However, the data show intertidal polychaetes to be abundant, diverse, and their distribution complex. The community, although homogeneous in some respects (i.e. dominated by detritus processors), is heterogeneous in others (i.e. species composition). As is typical of benthic assemblages, the regional species pool determined local scale richness, and the presence/absence of vegetation was influential in the benthic assemblages observed. Yet sites were unique and generalisations regarding habitat-specific fauna, although interesting, are of limited value. Further investigations into small-scale processes such as localised disturbance regimes (e.g. bioturbation) and species interactions, which may exert a greater effect on the distribution of polychaete species in the region, together with polychaete life histories and large scale physical processes known to affect benthic communities, will provide a better understanding of how polychaete community structure and diversity are maintained.

\section{ACKNOWLEDGEMENTS}

This work stemmed from a European Union funded Capacity Building Project. The authors are most grateful for all the help, research facilities and hospitality provided by all staff at the Ranong Coastal Resource Research Station (Thailand). Dave Parry and Steve Widdicombe helped in the sampling design, collection and processing of samples. 


\section{REFERENCES}

Al-Hakim, I. and C.J. Glasby. - 2004. Polychaeta (Annelida) of the Natuna Islands, South China Sea. Raffles Bull.Zool., Suppl. 11: $25-45$.

Alongi, D.M. - 1990. - The ecology of tropical soft-bottom benthic ecosystems. Oceanogr. Mar. Biol. Ann. Rev., 28: 381-496.

Angsupanich, S. and R. Kuwabara. - 1995. Macrobenthic fauna in Thale Sap Songkla, a brackish lake in southern Thailand. Lakes \& Resevoirs: Reserves and Management, 1: 115-125.

Angsupanich, S. and R. Kuwabara. - 1999. Distribution of macrobenthic fauna in Phawong and U-Taphao canals flowing into a lagoonal lake, Sonhkgla, Thailand. Lakes \& Resevoirs: Reserves and Management, 4: 1-13.

Ansari, Z.A., C.U. Rivonker, P. Ramani and A.H. Parulekar. 1991. Seagrass habitat complexity and macroinvertebrate abundance in Lakshadweep coral-reef lagoons, Arabian Sea. Coral Reefs, 10: 127-131.

Aungtonya, C., S. Thaipal and S. Bussarawit. - 2002. A list of polychaetes (Annelida) in the reference collection database of the Phuket Marine Biological Center, Thailand. In: D. EibyeJacobsen (ed.), Proceedings of the International Workshop on the Polychaetes of the Andaman Sea, pp. 21-32. Phuket Marine Biological Center Special Publication, Phuket, Thailand.

Baoling, W., S. Ruiping and D.J. Yang. - 1985. The Nereidae (polychaetous annelids) of the Chinese coast. China Ocean Press, Beijing.

Boonlert, P. - 1992. Preliminary report on the polychaetes from the fifth Thai-Danish expedition along the Andaman Sea coast of Thailand. Phuket Mar. Biol. Cent. Res. Bull., 57: 77-88.

Chansang, H. and S. Poovachiranon. - 1994. The distribution and species composition of seagrass beds along the Andaman Sea coast of Thailand. Phuket Mar. Biol. Cent. Res. Bull., 59: 43-52.

Clarke, K.R. and R.M. Warwick. - 1997. Change in marine communities: An approach to statistical analysis and interpretation. Plymouth Marine Laboratory, Natural Environmental Research Council, UK, Plymouth.

Colwell, R.K. - 1997. Estimates: Statistical estimation of species richness and shared species from samples, version 5. User's guide and application. Department of Ecology and Evolutionary Biology, University of Connecticut Storrs, CT, USA.

Colwell, R.K. and J.A. Coddington. - 1994. Estimating terrestrial biodiversity through extrapolation. Phil. Trans. R. Soc. London B, Biol. Sc., 345: 101-118.

Constable, A.J. - 1999. Ecology of benthic macro-invertebrates in soft-sediment environments: A review of progress towards quantitative models and predictions. Australian J. Ecol., 24: 452-476.

Dexter, D.M. - 1996. Tropical sandy beach communities of Phuket island, Thailand. Phuket Mar. Biol. Cent. Res. Bull., 61: 1-28.

Dittmann, S. - 2000. Zonation of benthic communities in a tropical tidal flat of north-east Australia. J. Sea Res., 43: 33-51.

Dittmann, S. and J.A. Vargas. - 2001. Tropical tidal flat benthos compared between Australia and Central America. In: K. Reise (ed.), Ecological comparisons of sedimentary shores. Ecol. Stud., 151: 275-293.

Edgar, G.J., C. Shaw, G.F. Watsona and L.S. Hammond. - 1994. Comparisons of species richness, size-structure and production of benthos in vegetated and unvegetated habitats in Western Port, Victoria. J. Exp. Mar. Biol. Ecol., 176: 201-226.

Edwards, A., P. Garwood and M.A. Kendall. - 1992. The Gann Flat, Dale: Thirty years on. Field Stud., 8: 59-75.

Eibe-Jacobsen, D. (ed.) - 2002. Proceedings of the international workshop on the polychaetes of the Andaman Sea. Phuket Mar. Biol. Cent. Sp. Publ. Phuket.

Ellingsen, K.E. and J.S. Gray. - 2002. Spatial patterns of benthic diversity: Is there a latitudinal gradient along the Norwegian continental shelf? J. Anim. Ecol., 71: 373-389.

Fauchald, K. and P.A. Jumars. - 1979. The diet of worms: A study of polychaete feeding guilds. Oceanogr. Mar. Biol. Ann. Rev., 17: 193-284.

Fauvel, P. - 1932a. Annelida Polychaeta of the Indian museum, Calcutta The Superintendent, Zoological Survey of India, Calcutta.

Fauvel, P. - 1932b. Polychètes nouvelles de Che-Foo (Chine). Mus. Hist. Nat. Paris. 2e Série, 4: 536-538.
Fauvel, P. - 1953. Annelida Polychaeta. The Indian Press, Ltd., Allahabad.

Gray, J.S. - 2002. Species richness of marine soft sediments. Mar. Ecol. Prog. Ser., 244: 285-297.

Gray, J.S., K.R. Clarke, R.M. Warwick and G. Hobbs. - 1990. Detection of initial effects of pollution on marine benthos - an example from the Ekofisk and Eldfisk oilfields, North Sea. Mar. Ecol. Prog. Ser., 66: 283-299.

Holme, N.A. - 1971. Methods for the study of marine benthos. In: N.A. Holme and A.D. McIntyre (eds.), IBP handbook, pp. 80130. Blackwell Scientific Publications, Oxford and Edinburgh.

Hutchings, P. - 1998. Biodiversity and functioning of polychaetes in benthic sediments. Biol. Cons., 7: 1133-1145.

Imaiima, M. - 1972. Review of the annelid worms of the family Nereidae of Japan, with descriptions of five new species or subspecies. Bull. Nat. Sc. Mus., 15: 37-154.

Lara, O.A.M. and J.A.V. Zamora. - 1994. Structure of the macrobenthos in Jaltepeque estuary, El Salvador. Rev. Biol. Trop., 42: $165-174$.

Lydy, M.J., C.G. Crawford and J.W. Frey. - 2000. A comparison of selected diversity, similarity, and biotic indices for detecting changes in benthic-invertebrate community structure and stream quality. Arch. Env. Cont. Tox., 39: 469-479.

McIntosh, D.J., E.C. Ashton and S. Havanon. - 2002. Mangrove rehabilitation and intertidal biodiversity: A study in the Ranong mangrove ecosytem, Thailand. Estuar. Coast. Shelf Sci., 55: 331-345.

Meksumpun, C. and S. Meksumpun. - 1999. Polychaete-sediment relations in Rayong, Thailand. Env. Poll., 105: 447-456.

Nateewathana, A. - 1992. Polychaetes of Thailand. Nereididae (part 3): Solomononereis phuketensis n. sp. from euhaline environments in the Andaman Sea. Phuket Mar. Biol. Cent. Res. Bull, 57: 89-96.

Nateewathana, A. and J. Hylleberg. - 1991. Magelonid polychaetes from Thailand, the Andaman Sea, with descriptions of eight new species. Ophelia, Suppl. 5: 169-184.

Patterson Edward, J.K. and K. Ayyakkannu. - 1992. Benthic macrofauna of Coleroon estuary, southeast coast of India. Phuket Mar. Biol. Cent. Res. Bull, 57: 67-76.

Pearson, T.H. and R. Rosenberg. - 1978. Macrobenthic succession in relation to organic enrichment and pollution of the marine environment. Oceanogr. Mar. Biol. Ann. Rev., 16: 229-311.

Petersen, G.H. and M.A. Curtis. - 1980. Differences in energy flow through major components of subarctic, temperate and tropical marine shelf ecosystems. Dana, 1: 53-64.

Phasuk, B. - 1992. Preliminary report on the polychaetes from the fifth Thai-Danish expedition along the Adaman Sea coast of Thailand. Phuket Mar. Biol. Cent. Res. Bull, 57: 77-88.

Reise, K. - 1991. Macrofauna in mud and sand of tropical and temperate tidal flats. In: M. Elliott and J.-P. Ducrotoy (eds.), Estuaries and coasts: Spatial and temporal intercomparisons, pp. 211-216. Olsen and Olsen, Fredensborg.

Rodriguez Villanueva, V., R. Martinez Lara and V. Macias Zamora. - 2003. Polychaete community structure of the northwestern coast of Mexico: Patterns of abundance and distribution. Hydrobiologia, 496: 385-399.

Sheridan, P. - 1997. Benthos of adjacent mangrove, seagrass and non-vegetated habitats in Rookery Bay, Florida, USA. Esuart. Coast. Shelf Sc., 44: 455-469.

Sokal, R.R. and F.J. Rohlf. - 1995. Biometry Freeman, New York.

Somaschini, A., M.F. Gravina and G.D. Ardizzone. - 1994. Polychaete depth distribution in a Posidonia oceanica bed (rhizome and matte strata) and neighboring soft and hard bottoms. Mar. Ecol. PSZN I, 15: 133-151.

Turner, S.J. and M.A. Kendall. - 1999. A comparison of vegetated and unvegetated soft-sediment macrobenthic communities in the River Yealm, south-western Britain. J. mar. biol. Ass. U. K., 79: 741-743.

Warwick, R.M. and Ruswahyuni. - 1987. Comparative-study of the structure of some tropical and temperate marine soft-bottom macrobenthic communities. Mar. Biol., 95: 641-649.

Washington, H.G. - 1984. Diversity, biotic and similarity indices: A review with special relevance to aquatic ecosystems. Water Res., 18: 653-694.

Received September 13, 2004. Accepted May 11, 2005. 